\title{
Pengaruh Teknik Budidaya Konversi Organik dan Konvensional Terhadap Keanekaragaman Arthropoda Herbivora dan Predator Tanaman Kedelai Edamame
}

\author{
Author(s): Liska Aningrum ${ }^{(1) *}$; Herlinawati $^{(1)}$ \\ (1) Jurusan Produksi Pertaniian, Politeknik Negeri Jember \\ * Corresponding author: liska.aningrum@gmail.com
}

\section{ABSTRAK}

Keanekaragaman arthropoda merupakan hal penting dalam pengelolaan hama, karena didalamnya mencakup herbivore, predator, dan parasioid yang menentukan teknik pengelolaan hama. Penelitian ini bertujuan untuk mengetahui keanekargaman arthropoda herbivor dan predator tanaman kedelai Edamame pada teknik budidaya konversi organik dan konvensional. Penelitian ini dilakukan pada bulan Maret-Mei 2019 di desa Dukuh Mencek, Kecamatan Sukorambi, Kabupaten Jember dengan membandingkan dua lokasi berbeda. Lokasi pertama yaitu budidaya kedelai Edamame konversi organik yang menggunakan pestisida nabati kombinasi, pupuk organik padatan. Lokasi kedua yaitu lahan teknik budidaya konvensional menggunakan pupuk anorganik dan pestisida sintetik. Analisa data menggunakan uji non parametrik statistik menggunakan perangkat lunak SPPS versi 25,0. Hasil penelitian menunjukkan bahwa herbivora pada budidaya konversi organik terdapat 4 ordo, 9 famili, 14 spesies, 2426 individu dan predator 6 ordo, 8 famili, 8 spesies, 831 individu, Indeks Diversitas (H') yaitu 1,18, Indeks Dominansi (C) yaitu 0,53 , jumlah polong 26,500 , dan untuk berat polong yaitu $46,960 \mathrm{~g}$. Sedangkan pada budidaya konvensional menunjukkan herbivora terdapat 4 ordo, 9 famili, 15 spesies, 1622 individu, dan predator 6 ordo, 10 famili, 11 spesies, 730 individu, Indeks Diveritas (H') yaitu 1,52, Indeks Dominansi (C) yaitu 0,38 , jumlah polong 30,020, dan berat polong yaitu $52,720 \mathrm{~g}$.
\end{abstract}

\section{Kata Kunci:}

Budidaya

konversi

organik;

Herbivor;

Konvensional;

Predator;

\begin{abstract}
Keywords: $\quad$ Arthropod diversity is important in pest management, because it includes herbivores, Conventiona; predators, and parasioids that determine pest management techniques. This study aims to determine the diversity of herbivore and predators arthropods of Edamame soybean Herbivore; $\quad$ plants in organic conversion cultivation techniques and conventional. This research was conducted in March-May 2019 in the village of Dukuh Mencek, Sukorambi District, Organic Jember Regency with comparing two different locations. The first location is the conversion cultivation of organic conversion Edamame soybean using combination plant-based cultivation; pesticides, solid organic fertilizer. The second location is conventional cultivation Predator; $\quad$ techniques using inorganic fertilizers and synthetic pesticides. Data analysis using nonparametric statistical tests using SPPS software version 25.0. The results showed that herbivores in organic conversion cultivation were 4 orders, families, 14 species, 2426 individuals and predators of 6 orders, 8 families, 8 species, 831 individuals, the Diversity Index ( $\left.H^{\prime}\right)$ was 1,18, the Dominance Index $(C)$ was 0,53 , the number of pods was 26,500, and the weight of the poll was 46,960 $\mathrm{g}$. Whereas on conventional cultivation there are 4 orders of herbivores, 9 families, 15 species, 1622 individuals, and predators of 6 orders, 10 families, 11 species, 730 individuals, the Diverity Index ( $\left.H^{\prime}\right)$ shows 1.53, the Dominance Index $(C)$ is 0,38, the number of pods is 30.020, and the pod weight is 52, 720 $g$.
\end{abstract}




\section{PENDAHULUAN}

Kedelai Edamame adalah jenis kedelai dari negara Jepang dan telah berhasil dikembangkan di Indonesia. Tanaman kedelai Edamame berbeda dengan tanaman kedelai pada umumnya, karena umur panennya lebih pendek dan memiliki nilai jual lebih tinggi. Salah satu permasalahan yang dihadapi petani dalam melakukan budidaya kedelai Edamame yaitu adanya serangan berbagai jenis serangga hama. Sejak tanaman kedelai Edamame mulai tumbuh dapat diserang oleh hama hingga menjelang panen. Serangan hama-hama pada tanaman Edamame dapat mengakibatkan kehilangan hasil panen Edamame hingga 80\% . (Meithasari et al., 2014).

Bagi suatu ekosistem pertanian Arthropoda memiliki beberapa peran penting dan dapat ditemukan komunitas Arthropoda yang terdiri dari berbagai jenis dimana masing-masing jenis memperlihatkan sifat populasinya yang khas. Tidak semua jenis dari Arthropoda merupakan hama, namun dapat berperan juga sebagai musuh alami baik sebagai predator, parasitoid, serangga penyerbuk, maupun dekomposer. Keberadaan musuh alami di lapang dapat dipengaruhi oleh keberadaaan hama (Nelly, 2012).

Menurut Hildrew \& Townsend (1982) kelimpahan dari suatu mangsa atau hama dapat menarik datangnya predator dan diikuti oleh meningkatnya kemampuan predator untuk memangsa. Pada suatu ekosistem, keragaman hama yang berbeda memungkinan tersedianya musuh alami yang beragam pula, selain itu dampak atau pengaruh dari tingkat keanekaragaman arthropoda juga sangat penting. Keanekaragaman arthropoda juga memiliki pengaruh atau dampak terhadap kualitas dan kuantitas produk yang dihasilkan. Pada suatu ekosistem alami keberadaan serangga hama tidak lagi merugikan karena terjadi kestabilan antara kelimpahan hama dan musuh alaminya.
Kondisi tersebut perlu untuk dikembangkan lagi di lapang sehingga dapat menekan penggunaan pestisida dalam mengendalikan serangan hama (Widiarta et al., 2012).

Adanya perbedaan teknik budidaya berpengaruh pada populasi dan tingkat keanekaragaman arthropoda. Keanekaragaman pada sistem pertanian konversi organik lebih baik apabila dibandingkan dengan pertanian konvensional. Hal ini dikarenakan pada lahan organik sistem budidaya yang diterapkan yaitu menggunakan pestisida nabati kombinasi dan pupuk organik padat, sedangkan pada lahan budidaya konvensional menggunakan insektisida sintetik (Pradhana et al., 2014).

Penelitian ini membandingkan keanekaragaman arthropoda meliputi herbivora dan predator pada tanaman kedelai Edemame antara budidaya konvensional yang dikonversi untuk menjadi organik dan budidaya konvensional seperti petani pada umumnya.

\section{METODOLOGI \\ BAHAN DAN METODE}

Penelitian ini dilaksanakan di Desa Dukuh Mencek, Kecamatan Sukorambi, Kabupaten Jember $08^{\circ} 10^{\prime}$ LS $113^{\circ} 39^{\prime}$ BT pada bulan Maret 2019 sampai Mei 2019. Penelitian dilaksanakan pada dua lokasi pertanaman Edamame dengan teknik budidaya berbeda yaitu lahan konversi organik dan lahan konvensional.

Bahan yang digunakan yaitu benih kedelai Edamame varietas Ryoko, Pupuk kandang sapi, Pupuk organik granul, Pestisida nabati kombinasi ekstrak daun Kenikir dan Serai wangi, Pupuk Urea, TSP, Phonska, ZA, Pestisida sintetik berbahan aktif Imidakloprid, alat tulis dan bukubuku identifikasi arthopoda, timbangan analitik dan tali rafia. 


\section{Teknik Pengumpulan Data}

Penelitian ini membandingkan keanekaragaman arthropoda, Indeks Shannon-Wiener, Indeks Dominansi, jumlah polong per rumpun, dan berat polong per rumpun antara dua lahan yang ditanami kedelai Edamame secara konversi organik dan konvensional. Masing-masing lahan memiliki luas $100 \mathrm{~m}^{2}$ dengan pengambilan sampel masing-masing 50 rumpun secara zig-zag.

\section{1.) Budidaya Konversi Organik}

Metode penelitian pada lahan budidaya konversi organik yaitu menggunakan benih kedelai Edamame varietas Ryoko diisi per lubang tanam 1 benih dengan menggunakan jarak tanam 25 $\mathrm{cm} \times 20 \mathrm{~cm}$ pada luasan lahan $10 \mathrm{~m}^{2}$ dengan jumlah populasi 200 tanaman per plot. Pupuk yang digunakan yaitu pupuk organik dengan pemupukan pertama menggunakan pupuk kandang sapi sebanyak 20 ton/Ha, pemupukan berikutnya menggunakan pupuk organik granul sebanyak 6-7 ton/Ha, serta menggunakan pestisida nabati kombinasi ekstrak daun kenikir dan serai wangi dengan konsentrasi $15 \%$ dan dosis 500 L/Ha diaplikasikan 5 hari sekali.

\section{2.) Budidaya Konvensional}

$\begin{array}{lll}\text { Metode penelitian pada lahan } \\ \text { budidaya } & \text { konvensional } & \text { yaitu }\end{array}$
menggunakan benih kedelai Edamame varietas ryoko diisi per lubang tanam dengan 1 benih dengan menggunakan jarak tanam $25 \mathrm{~cm} \times 20 \mathrm{~cm}$ pada luasan lahan 10 $\mathrm{m}^{2}$ dengan jumlah populasi 200 tanaman per plot. Pupuk yang digunakan yaitu pupuk Urea $200 \mathrm{~kg} / \mathrm{Ha}$, TSP $100 \mathrm{~kg} / \mathrm{Ha}$, Phonska $100 \mathrm{~kg} / \mathrm{Ha}, \mathrm{Za} 100 \mathrm{~kg} / \mathrm{Ha}$ pada pemupukan awal dan pemupukan kedua dengan Urea $200 \mathrm{~kg} / \mathrm{Ha}$, Phonska 200 $\mathrm{kg} / \mathrm{Ha}$, Za $100 \mathrm{~kg} / \mathrm{Ha}$, dan dilakukan penyemprotan insektisida dan fungisida sintetik dengan insektisida berbahan aktif Imidakloprid dengan konsentrasi $2 \mathrm{ml} / \mathrm{L}$ diaplikasikan setiap 5 hari sekali, dan fungisida Topsin berbahan aktif Metil Tiofanant dengan konsentrasi $4 \mathrm{~g} / \mathrm{L}$ dan dosis $500 \mathrm{~L} / \mathrm{Ha}$.

\section{Parameter Pengamatan}

Keanekaragaman arthropoda meliputi jumlah ordo, family, spesies, herbivora, dan predator, Indeks Diversitas Shannon-Wiener $\left(\mathrm{H}^{\prime}\right)$, Indeks Dominansi (C), Jumlah polong dan Berat polong per rumpun.

Data dianalisis menggunakan analisis non parametrik dengan SPSS versi 25,0 Indeks diversitas Shannon-Wiener (H') menggunakan rumus:

$$
\mathrm{H}^{\prime}=\underset{\mathrm{pi}=\frac{n i}{N}}{-\mathrm{pi}^{\mathrm{in}} \ln \mathrm{pi}}
$$

Keterangan:

H' = Indeks Diversitas Shannon-Wiener,

pi $=$ Perbandingan jumlah individu spesies ke-i dengan jumlah total seluruh individu spesies,

ni = Jumlah individu spesies ke-i,

$\mathrm{N}=$ Jumlah total seluruh individu spesies.

Kriteria indeks diversitas Shannon-Wiener (Yaherwandi et al., 2007).

Indeks Dominansi menggunakan rumus:

$\mathrm{C}=\sum \mathrm{pi}^{\wedge} 2$

Keterangan :

$\mathrm{C}$ adalah Indeks Dominansi,

pi adalah Jumlah individu dalam satu spesies dibagi jumlah total seluruh individu dari spesies yang ditemukan.

Kriteria Indeks Dominansi:

Apabila nilai $\mathrm{C}$ mendekati $0(<0.5)$, maka tidak ditemukan adanya spesies yang mendominansi

Apabila nilai $\mathrm{C}$ mendekati $1(\geq 0.5)$, maka ditemukan adanya spesies yang mendominansi

\section{Hasil panen}

Untuk pengamatan produksi tiap plot pada masing-masing perlakuan dengan menghitung berat produksi Edamame dalam setiap sample kemudian ditimbang berat polong dengan satuan gram per plot pada masing-masing sample. Pemanenan pada tanaman dilakukan pada umur 70 hari setelah tanam. Dan ditandai dengan polong bernas. 


\section{Analisis Data}

Data diolah menggunakan perangkat lunak SPSS versi 25,0 dengan membandingkan antara budidaya konversi organik dan konvensional meliputi:

a) Normalitas data dengan analisis non parametrik menggunakan KolmogorovSmirnov.

b) Homogenitas data menggunakan OneWay ANOVA
Jika data normal dan homogen diuji lanjut menggunakan Paired Sample TTest

c) Apabila data tidak normal dan atau tidak homogen maka diuji lanjut dengan non parametrik menggunakan MannWhitney.

Data Indeks Diversitas ShannonWiener (H') dan Indeks Dominansi (C) menggunakan perangkat lunak Microsoft Excell 2019.

Tabel 1. Nilai dan deskripsi Indeks diversitas Shanon-Wiener ( $\left.\mathrm{H}^{\prime}\right)$

Table 1. Value and description of Shanon-Wiener diversity index $\left(H^{\prime}\right)$

$\begin{array}{lll}\mathrm{H}^{\prime}<1.0 & 1.0<\mathrm{H}^{\prime}<3.22 & \mathrm{H}^{\prime}>3.22\end{array}$

\begin{tabular}{lcc}
\hline - Diversitas rendah & - Diversitas sedang & - Diversitas tinggi \\
Low diversity & Medium diversity & High diversity \\
- Prduktivitas rendah & - Prduktivitas sedang & - Prduktivitas tinggi \\
Low productivity & Medium productivity & High productivity \\
- Ekosistem tidak stabil & - Ekosistem seimbang & - Ekosistem stabil \\
Unstable ecosystem & Balanced ecosystem & Stable ecosystem \\
\hline
\end{tabular}

HASIL DAN PEMBAHASAN

Keanekaragaman Arthropoda pada teknik budidaya kedelai Edamame konversi organik dan konvensional

Berdasarkan penelitian yang telah dilakukan jumlah keseluruhan Arthopoda yang telah dikumpulkan pada tanaman kedelai Edamame konversi organik dan konvensional dari jumlah sepesies rata-rata dari kedua perlakuan yaitu berbeda untuk herbivora yaitu pada budidaya konversi organik terdapat 4 ordo, 9 famili, 14 spesies, 2426 individu dan predator 6 ordo, 8 famili, 8 spesies, 831 individu, sedangkan untuk budidaya konvensional sendiri yaitu untuk herbivora terdapat 4 ordo, 9 famili, 15 spesies, 1622 individu, dan predator 6 ordo, 10 famili, 11 spesies, 730 individu.

Untuk kenaikan jumlah individu, spesies, famili pada fase pertumbahan generatif lebih tinggi dibanding pada fase vegetatif. Kenaikan arthopoda predator mengalami peningkatan yang sejalan dengan pertumbuhan tanaman kedelai
Edamame konversi organik dengan pengaplikasian pestisida nabati kombinasi yang menyebabkan dilahan budidaya konversi organik predator tinggi. Keanekaragaman dapat dipengaruhi dengan agroekositem dan pertambahan umur tanaman kedelai Edamame yang menyebabkan perubahan bentuk dan ukuran tanaman sehingga dapat ditempati oleh arthopoda hama dan menyediakann lebih banyak relung yang berikutnya yaitu arthopoda predator.

Keanekaragaman dan kelimpahan individu arthropoda pada teknik budidaya konversi organik lebih besar dibanding konvensional. Hal ini dapat disebabkan oleh aplikasi insektisida sintetik pada teknik budidaya konvensional telah menyebabkan perubahan pada agroekosistem. Agroekosistem yang terganggu akibat insektisida sintetik akan menyebabkan penurunan keanekaragaman arthropoda (Adhitya et al., 2013). 
Tabel 1. Jumlah ordo, famili, spesies dan jumlah individu herbivora dan predator

Table 1. The number of ordo, family, species and the number of individual herbivore and predator

\begin{tabular}{lcr}
\hline Filum Arthropoda & \multicolumn{2}{c}{ Teknik Budidaya } \\
Arthropod phylum & \multicolumn{2}{c}{ Cultivation technique } \\
\cline { 2 - 3 } & Konversi Organik & Konvensional \\
& Organic conversion & Conventional \\
\hline Herbivora: & 4 Ordo & 4 Ordo \\
Herbivore & 9 Famili & 9 Famili \\
& 14 Spesies & 15 Spesies \\
& 2426 Individu & 1622 Individu \\
\hline Predator: & 6 Ordo & 6 Ordo \\
Predator & 8 Famili & 10 Famili \\
& 8 Spesies & 11 Spesies \\
& 831 Individu & 730 Individu \\
\hline
\end{tabular}

Berdasarkan hasil pada Tabel 2., yang menyatakan keanekaragaman fungsional arthropoda pada budidaya konversi organik dan konvensional dengan simbol $(+)$ menyatakan bahwa adanya arthropoda pada lahan budidaya yang diterapkan. Sedangkan untuk simbol (-) menyatakan bahwa tidak adanya arthropoda pada lahan budidaya.

Arthropoda terbanyak yang ditemukan di lahan budidaya adalah arthropoda yang memiliki status fungsi sebagai herbivora. Serangga terbanyak yang terdapat di lapangan adalah serangga yang memiliki status fungsi sebagai hama (Sidabutar et al., 2017). Hal ini disebabkan di lapangan hanya ada tanaman kedelai, sehingga tanaman monokultur akan mengubah populasi berbagai hama berkembang dengan cepat. Selain itu didukung oleh Susniahti et al (2005) yang menyatakan pada suatu ekosistem alami makanan serangga hama terbatas dan musuh alami dapat berperan aktif sehingga populasi serangga hama tersebut rendah. Sebaliknya pada suatu ekosistem monokultur makanan serangga hama relatif tidak terbatas atau melimpah sehingga populasi serangga hama bertambah dengan cepat tanpa dapat diimbangi oleh peran musuh alaminya. Dan akibat dari jumlah serangga hama yang lebih banyak adalah kerusakan yang dapat merugikan secara ekonomi.

Tabel 2. Keanekaragaman Fungsional Arthropoda pada budidaya konversi organik dan konvensional

Table 2. Arthropod Functional Diversity in organic conversion cultivation and conventional

\begin{tabular}{|c|c|c|c|c|c|c|}
\hline \multirow[t]{2}{*}{ No } & \multirow[t]{2}{*}{$\begin{array}{l}\text { Nama Serangga } \\
\text { Name of insect }\end{array}$} & \multirow[t]{2}{*}{$\begin{array}{l}\text { Ordo } \\
\text { Order }\end{array}$} & \multirow[t]{2}{*}{$\begin{array}{l}\text { Famili } \\
\text { Family }\end{array}$} & \multirow[t]{2}{*}{$\begin{array}{c}\text { Peran } \\
\text { Role }\end{array}$} & \multicolumn{2}{|c|}{$\begin{array}{c}\text { Teknik } \\
\text { Budidaya } \\
\text { Cultivation } \\
\text { techniques }\end{array}$} \\
\hline & & & & & KO & $\mathrm{K}$ \\
\hline 1. & Bemisia tabaci Gennadius & Hemiptera & Aleyrodidae & Herbivora & + & + \\
\hline 2. & Atractomorpha crenulata & Orthoptera & Pyrgomorphidae & Herbivora & + & + \\
\hline 3. & Argiope bruennichi & Araneae & Araneidae & Predator & - & + \\
\hline 4. & Argiope catenulata & Araneae & Araneidae & Predator & - & + \\
\hline 5. & Conocephalus sp & Orthoptera & Tettigoniidae & Predator & + & + \\
\hline 6. & Dissosteria carolina & Orthoptera & Acrididae & Herbivora & + & + \\
\hline 7. & Formica rufa & Hymenoptera & Formicidae & Predator & + & + \\
\hline
\end{tabular}




\begin{tabular}{|c|c|c|c|c|c|c|}
\hline 8. & Heliohis armigera & Lepidoptera & Noctuidae & Herbivora & - & + \\
\hline 9 & Ischnura sp & Odonata & Coenagrionidae & Predator & + & + \\
\hline 10. & Lamprosema indicata & Lepidoptera & Pyralidae & Herbivora & + & + \\
\hline 11. & Leptocorisa acuta & Hemiptera & Alydidae & Herbivora & + & + \\
\hline 12. & Mantis religiosa & Mantodae & Mantidae & Predator & + & + \\
\hline 13. & Melanagromyza sojae & Diptera & Agromyzidae & Herbivora & + & + \\
\hline 14. & Metioche vittaticollis & Orthoptera & Gryllidae & Predator & + & + \\
\hline 15. & Micraspis sp & Coleoptera & Coccinellidae & Predator & + & + \\
\hline 16. & Musca sorben & Diptera & Muscidae & Herbivora & + & + \\
\hline 17. & Nezara viridula Linneaeus & Hemiptera & Pentatomidae & Herbivora & + & + \\
\hline 18. & Orthetrum sabina & Odonata & Libellulidae & Predator & + & + \\
\hline 19. & Ophiomysia phaseoli & Diptera & Agromyzidae & Herbivora & + & + \\
\hline 20. & Oxya spp & Orthoptera & Acrididae & Herbivora & + & + \\
\hline 21. & Oxyopes sp & Araneae & Oxyopidae & Predator & + & + \\
\hline 22. & Paederus fuscipes & Coleoptera & Carabidae & Predator & - & + \\
\hline 23. & Phlaeoba fumosa & Orthoptera & Acrididae & Herbivora & + & + \\
\hline 24. & Riptortus linearis fabricius & Hemiptera & Alydidae & Herbivora & + & + \\
\hline 25. & Spodoptera litura $\mathrm{F}$. & Lepidoptera & Noctuidae & Herbivora & + & + \\
\hline 26. & Valanga nigricornis & Orthoptera & Acrididae & Herbivora & + & + \\
\hline
\end{tabular}

Keterangan:

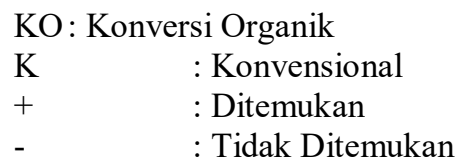

Noted

KO: Organic conversion
$\mathrm{K}$
+

Indeks Diversitas Shannon -Wiener (H') dan Indeks Dominansi (C)

Tabel 3. Indeks Diversitas

Table 3. Diversity index

\begin{tabular}{lcc}
\hline \multirow{2}{*}{$\begin{array}{c}\text { Indeks Diversitas } \\
\text { Diversity index }\end{array}$} & \multicolumn{2}{c}{ Teknik Budidaya } \\
& Cultivation techniques \\
\cline { 2 - 3 } & Konversi Organik & Konvensional \\
& Organic conversion & Conventional \\
\hline Shannon-Wiener $\left(\mathrm{H}^{\prime}\right)$ & $1.176 \pm 0,700$ & $1,522 \pm 0,793$ \\
Dominansi (C) & $0,531 \pm 0,279$ & $0,377 \pm 0,286$ \\
\hline
\end{tabular}

Berdasarkan analisis Indeks Diversitas $\left(\mathrm{H}^{\prime}\right)$ pada teknik budidaya konversi organik lebih rendah, hal ini dapat dikarenakan jumlah spesies Arthropoda yang ditemukan pada lahan konversi organik lebih rendah dibanding konvensional. Indeks Dominansi (C) pada teknik budidaya konversi organik lebih tinggi dibandingkan dengan budidaya konvensional, hal ini disebabkan terdapat dominansi spesies pada teknik budidaya konversi organik yaitu dominansi Bemisia tabaci Genn. Hal ini sesuai dengan pendapat Arifin \& Bendell-Young (1997) jenis arthropoda dapat dipengaruhi oleh pestisida. Pestisida secara langsung berpengaruh pada fauna tanah dan secara tidak langsung dampak aplikasi insektisida melalui rantai makanan (Suhartini et al., 2017).

Aktivitas predator dapat mempengaruhi tingkat kerentanannya 
terhadap insektisida. Predator atau musuh alami yang aktif bergerak, lebih rentan terhadap insektisida karena lebih sering kontak dengan residu insektisida yang menempel pada permukaan tanaman. Insektisida secara tidak langsung juga dapat berpengaruh terhadap predator karena memangsa hama yang sudah terkontaminasi oleh insektisida. Herbivora mempunyai enzim yang mampu untuk mendetoksikasi senyawa beracun yang dimakannya, sedangkan predator tidak memiliki enzim tersebut.

\section{Hasil Panen Kedelai Edamame}

Tabel 4. Jumlah Polong Total, Jumlah Polong Diterima Perusahaan, dan Berat Polong Total per rumpun

Table 4. Total number of pods, number of pods accepted by the company, and total weight of pods by clump

\begin{tabular}{|c|c|c|c|}
\hline \multirow{4}{*}{$\begin{array}{c}\text { Teknik Budidaya } \\
\text { Cultivation } \\
\text { techniques }\end{array}$} & \multicolumn{3}{|c|}{$\begin{array}{c}\text { Rataan } \pm \mathrm{SD} \\
\text { Mean } \pm S D\end{array}$} \\
\hline & \multicolumn{2}{|c|}{$\begin{array}{l}\text { Jumlah Polong } \\
\text { number of pods }\end{array}$} & \multirow{3}{*}{$\begin{array}{l}\text { Berat Polong } \\
\text { Total } \\
\text { Total weight of } \\
\text { pods }\end{array}$} \\
\hline & & Polong Diterima & \\
\hline & $\begin{array}{l}\text { Polong Total } \\
\text { Total of pods }\end{array}$ & $\begin{array}{c}\text { Perusahaan } \\
\text { Pods accepted by the } \\
\text { company }\end{array}$ & \\
\hline Konversi Organik & $26,500 \pm$ & & \\
\hline $\begin{array}{l}\text { Organic } \\
\text { conversion }\end{array}$ & $9,396^{\mathrm{a}}$ & $9,700 \pm 5,206^{\mathrm{a}}$ & $46,960 \pm 18,321^{\mathrm{a}}$ \\
\hline Konvensional & $30,020 \pm$ & $10,120 \pm 6,333^{\mathrm{a}}$ & $52,720 \pm 25,282^{a}$ \\
\hline Conventional & $13,137^{\mathrm{a}}$ & & \\
\hline
\end{tabular}

Keterangan: Angka rataan yang diikuti huruf yang sama menunjukkan berbeda tidak nyata menurut Mann Whitney $(\mathrm{p}>0.05)$.

Note: $\quad$ The average number followed by the same letter shows non significant by Mann Whitney ( $p>$ $0.05)$.

Tabel 5. Berat Polong Diterima Perusahaan per rumpun

Table 5. Weight of pods accepted by the company of clump

\begin{tabular}{lc}
\hline $\begin{array}{l}\text { Teknik Budidaya } \\
\text { Cultivation techniques }\end{array}$ & $\begin{array}{l}\text { Rataan } \pm \mathrm{SD} \\
\text { Mean } \pm S D\end{array}$ \\
\hline $\begin{array}{l}\text { Konversi Organik } \\
\text { Organic conversion }\end{array}$ & $24,340 \pm 14,064^{\mathrm{a}}$ \\
$\begin{array}{l}\text { Konvensional } \\
\text { Conventional }\end{array}$ & $26,160 \pm 16,277^{\mathrm{a}}$ \\
\hline Keterangan: & $\begin{array}{l}\text { Angka rataan yang diikuti huruf yang sama menunjukkan berbeda tidak nyata menurut Paired } \\
\text { Samples T-Test }(\mathrm{p}>0.05) . \\
\text { The average number followed by the same letter shows non significant by Paired Samples T-Test } \\
(p>0.05) .\end{array}$
\end{tabular}

Hasil panen baik untuk jumlah polong maupun berat polong menunjukkan berbeda tidak nyata, hal ini dapat disebabkan oleh jumlah herbivore pada teknik budidaya konversi organik dan konvensional juga menunjukkan berbeda tidak nyata seperti yang ditunjukkan pada Tabel 6. 
Tabel 6. Jumlah Herbivore

Table 6. Number of herbivore

\begin{tabular}{ll}
\hline $\begin{array}{l}\text { Teknik Budidaya } \\
\text { Cultivation techniques }\end{array}$ & $\begin{array}{l}\text { Rataan } \pm \mathrm{SD} \\
\text { Mean } \pm S D\end{array}$ \\
\hline $\begin{array}{l}\text { Konversi Organik } \\
\text { Organic conversion }\end{array}$ & $303,250 \pm 219,732^{\mathrm{a}}$ \\
$\begin{array}{l}\text { Konvensional } \\
\text { Conventional }\end{array}$ & $202,720 \pm 200,483^{\mathrm{a}}$ \\
\hline Keterangan: & $\begin{array}{l}\text { Angka ratan yang diikuti huruf yang sama menunjukkan berbeda tidak nyata menurut Paired } \\
\text { Samples T-Test (p>0.05). } \\
\text { The average number followed by the same letter shows non significant by Paired Samples T-Test } \\
(p>0.05) .\end{array}$
\end{tabular}

Berdasarkan analisa regresi Koefisien Determinasi $\left(\mathrm{R}^{2}\right)$ menunjukkan polong maupun berat polong. Pada teknik budidaya konversi organik hubungan hubungan antara jumlah populasi individu herbivora dengan jumlah polong (total dan diterima perusahaan) maupun hubungan antara jumlah populasi individu herbivora dengan berat polong (total dan diterima perusahaan) baik pada teknik budidaya konversi organik maupun pada teknik budidaya konvensional itu sangat rendah artinya jumlah populasi individu herbivora tidak secara langsung berpengaruh terhadap hasil panen baik pada jumlah antara jumlah populasi individu herbivora dengan jumlah polong yaitu $0,59 \%$ dan hubungan antara jumlah populasi individu herbivora dengan berat polong yaitu $0,43 \%$. Sedangkan pada teknik budidaya konvensional hubungan antara jumlah populasi individu herbivora dengan jumlah polong yaitu $0,23 \%$ dan hubungan antara jumlah populasi individu herbivora dengan berat polong yaitu $0,04 \%$.

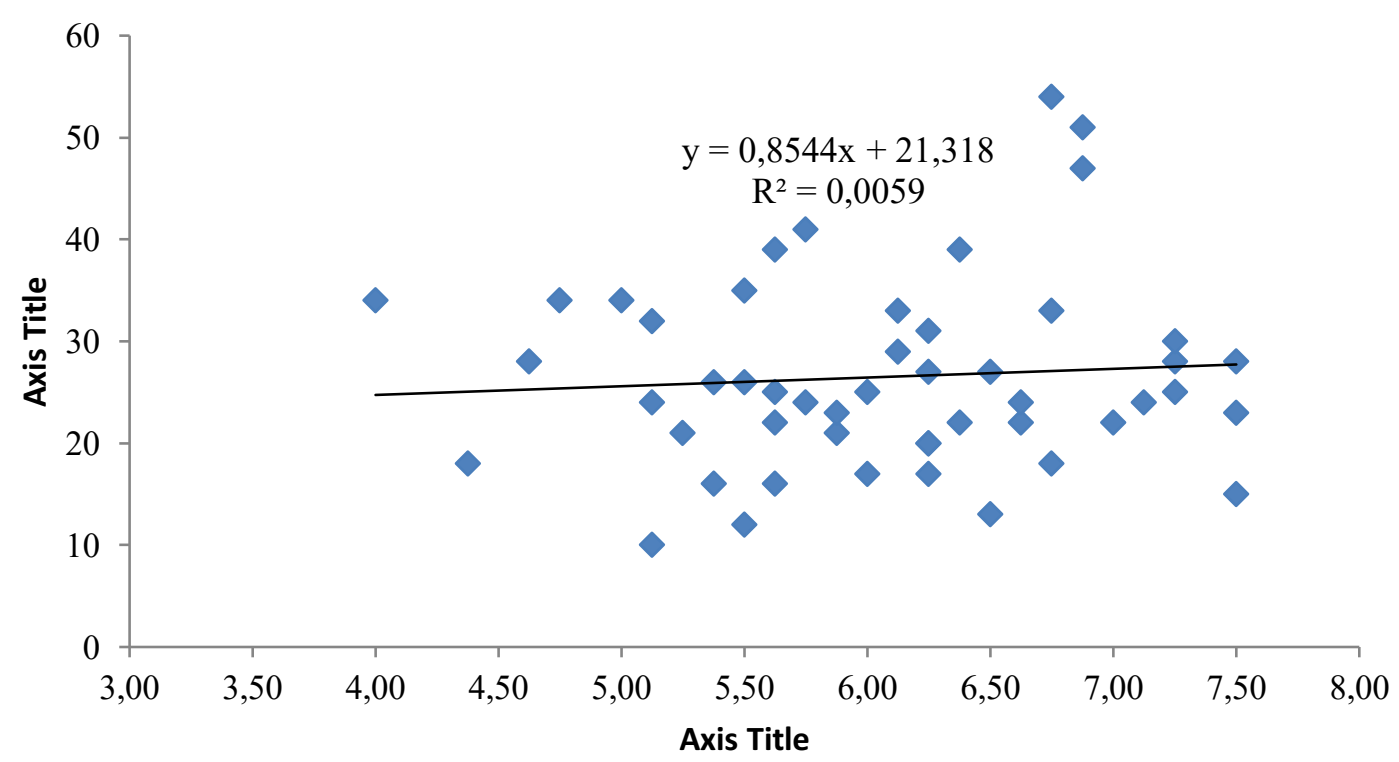

Gambar 1. Koefisien Diterminasi jumlah herbivora dan jumlah polong pada teknik budidaya konversi organik

Figure 1. Coefficient determined number of herbivore and number of pods in organic conversion cultivation technique 


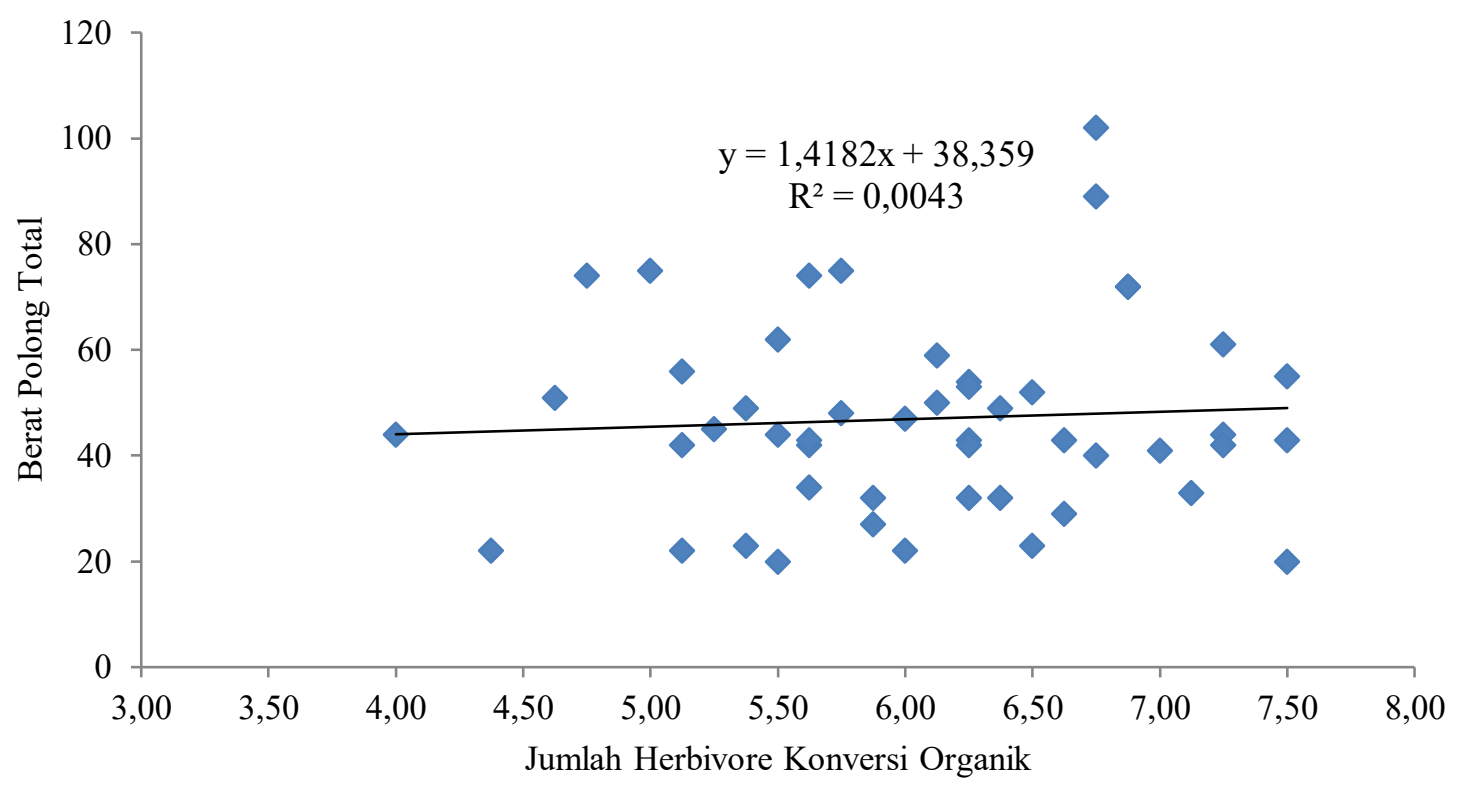

Gambar 2. Koefisien Diterminasi jumlah herbivora dan berat polong pada teknik budidaya konversi organik

Figure 2. Coefficient determined number of herbivore and weight of pods in organic conversion cultivation technique

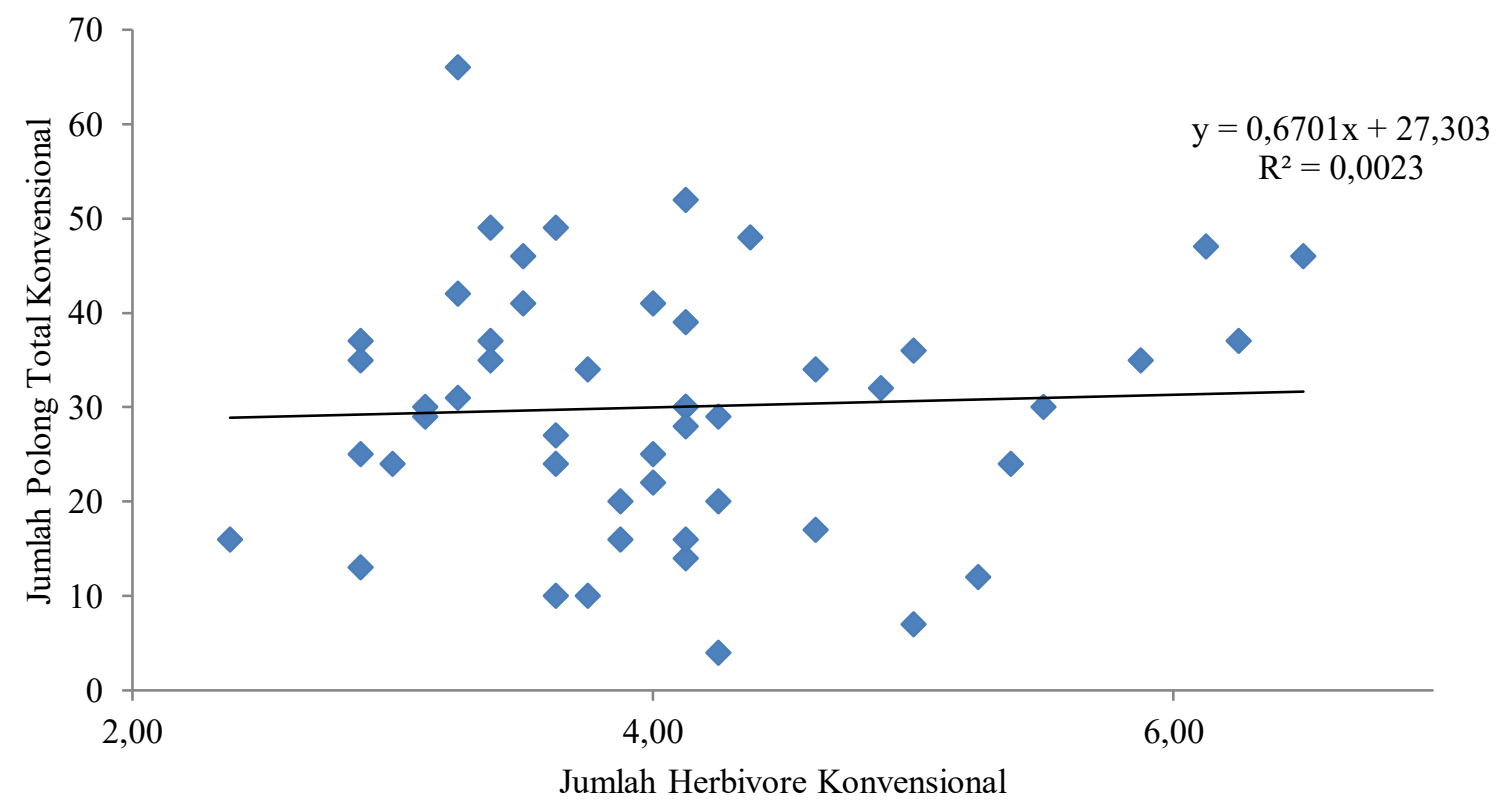

Gambar 3. Koefisien Diterminasi jumlah herbivora dan jumlah polong pada teknik budidaya konvensional

Figure 3. Coefficient determined number of herbivore and number of pods in conventional cultivation technique 


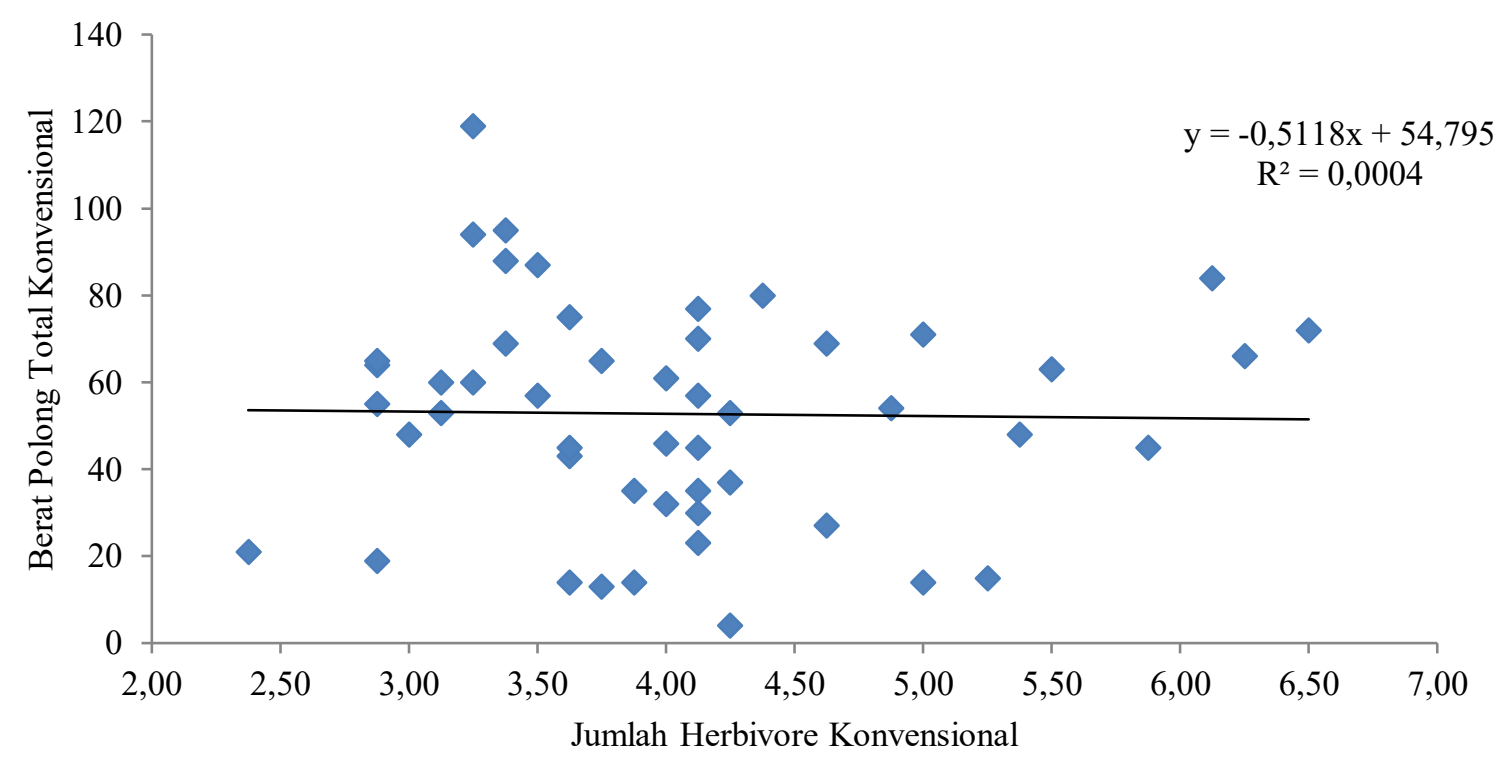

Gambar 4. Koefisien Diterminasi jumlah herbivora dan jumlah polong pada teknik budidaya konversi organik

Figure 4. Coefficient determined number of herbivore and weight of pods in conventional cultivation technique

Pada teknik budidaya konversi organik maupun konvensional untuk hasil panen baik jumlah polong (total dan diterima perusahaan) maupun berat polong (total diterima perusahaan) berbeda tidak nyata hal ini karena pengaplikasian pestisida nabati kombinasi dengan konsentrasi $15 \%$ sama hasilnya dengan pengaplikasian pestisida sintetik dengan konsentrasi $0,2 \%$. Aplikasi pestisida nabati yang berulang-ulang akan mengakibatkan penggunaan semakin efektif tetapi tidak membahayakan bagi tanaman serta tidak meninggalkan residu dalam tanaman. Keunggulan dari insektisida nabati yaitu murah, mudah untuk didapatkan dan juga mudah terurai di alam, selain itu insektisida nabati tidak meninggalkan residu pada tanaman karena memiliki fitotoksis dan toksisitas yang relatif rendah dan aman untuk serangga bukan sasaran (Tohir, 2010). Selain itu pada kedua lahan teknik budidaya kebutuhan unsur hara dapat dipenuhi oleh pengaplikasian pupuk organik maupun pupuk kimia. Pupuk organik berperan untuk memperbaiki sifat fisik tanah, dan menambah daya ikat tanah terhadap zat hara semakin tinggi sehingga tidak mudah larut dan terbawa oleh air hujan.

\section{KESIMPULAN}

Keanekaragaman arthropoda herbivora pada budidaya konversi organik terdapat 4 ordo, 9 famili, 14 spesies, 2426 individu dan predator 6 ordo, 8 famili, 8 spesies, 831 individu, Indeks Diversitas (H') yaitu 1,18, Indeks Dominansi (C) yaitu 0,53. Sedangkan pada budidaya konvensional menunjukkan herbivora terdapat 4 ordo, 9 famili, 15 spesies, 1622 individu, dan predator 6 ordo, 10 famili, 11 spesies, 730 individu, Indeks Diveritas (H') yaitu 1,52, Indeks Dominansi (C) yaitu 0,38 .

\section{DAFTAR PUSTAKA}

Adhitya, F. W., Hartono, D., \& Awirya, A. A. (2013). Determinan Produktivitas Lahan Pertanian Subsektor Tanaman Pangan di Indonesia. Jurnal Ekonomi Pembangunan, 14(1), 110125. 
Arifin, Z., \& Bendell-Young, L. (1997).

钢 Feeding response and carbon assimilation by the blue mussel Mytilus trossulus exposed to environmentally relevant seston matrices. Marine Ecology Progress Series, 160, 241-253. https://doi.org/10.3354/meps160241

Hildrew, A. G., \& Townsend, C. R. (1982).

钢 Predators and Prey in a Patchy Environment: A Freshwater Study. The Journal of Animal Ecology, 51(3), 797. https://doi.org/10.2307/ 4006

Meithasari, D., Diptaningsari, D., \& 琶 Hariyanto, B. (2014). Keanekaragaman Serangga Hama dan Musuh Alami pada Pertanaman Kedelai di Kebun Percobaan Natar dan Tegineneng. Prosiding Seminar Nasional Pengembangan Teknologi Pertanian, 225-230.

Nelly, N. (2012). Kelimpahan Populasi, 尌 Preferensi dan Karakter kebugaran Menochilus sexmaculatus (Coleoptera: Coccinellidae) Predator Kutudaun pada Pertanaman Cabai. Jurnal Hama Dan Penyakit Tumbuhan Tropika, 12(1), 46-55.

Pradhana, R. A. ., Mudjiono, G., \& EQ Karindah, S. (2014). Keanekaragaman Serangga dan Laba-Laba pada Pertanaman Padi Organik dan Konvensional. J. HPT Tropika, 2(2), 58-66.

Sidabutar, V., Marheni, \& Lubis, L. 的 (2017). Indeks Keanekaragaman Jenis Serangga pada Fase Vegetatif dan Generatif Tanaman Kedelai (Glycine maxMerill) di Lapangan. Jurnal Agroekoteknologi, 5(2), 474483.
Suhartini, S., Suryadarma, P., \& Budiwati, E. B. (2017). Pemanfaatan Pestisida Nabati Pada Pengendalian Hama Plutella Xylostella Tanaman Sawi (Brassica juncea L.) Menuju Pertanian Ramah Lingkungan. Jurnal Sains Dasar, 6(1), 36. https://doi.org/10.21831/jsd.v6i1.12 998

Susniahti, N., Sumeno., \& Sudarjat. EQ (2005). Bahan ajar ilmu hama tumbuhan. Universitas Padjajaran.

Tohir, A. M. (2010). Teknik Ekstraksi dan E Aplikasi Beberapa Pestisida Nabati untuk Menurunkan Palatabilitas Ulat Grayak (Spodoptera litura Fabr.) di Laboratorium. Buletin Teknik Pertanian, 15(1), 37-40.

Widiarta, I. N., Kusdiaman, D., \& E Suprihanto. (2012). Keragaman Arthropoda Pada Padi Sawah Dengan Pengelolaan Tanaman Terpadu. Jurnal Hama Dan Penyakit Tumbuhan Tropika, 6(2), 61-69.

Yaherwandi, Manuwoto, S., Buchori, D., Eidayat, P., \& Prasetyo, L. B. (2007). Keanekaragaman Hymenoptera Parasitoid pada Struktur Lanskap Pertanian Berbeda di Daerah Aliran Sungai (DAS) Cianjur, Jawa Barat. $J$. HPT Tropika, 7(1), 10-20. 